\title{
Damages caused by winter frosts, their temporal variation and frequencies in the main fruit growing region of Transdanubia and of the East Tisza regions of Hungary
}

\author{
Lakatos, L. ${ }^{1}$, Szőke, F. ${ }^{2}$, Szabó, Z. ${ }^{2}$, Soltész, M. ${ }^{2}$, Szalay, L. ${ }^{3} \&$ Nyéki, J. ${ }^{2}$ \\ ${ }^{1}$ University of Debrecen, Centre of Agricultural and Applied Economic Sciences, Department of Agricultural \\ Engeneering H-4032 Debrecen, Böszörményi 138, Hungary,lakatos@agr.unideb.hu \\ ${ }^{2}$ University of Debrecen, Institute of Horticulture, H-4032 Debrecen, Böszörményi 138, Hungary \\ ${ }^{3}$ University of Corvinus, Department of Pomology H-1118Budapest, Villányi 29-43.
}

\begin{abstract}
Summary: The aim of the study was the study of winter frost damages, especially their changes expressed in temporal frequencies on the main fruit growing regions of the country. In our earlier paper, we introduced the calculation with the term LT50 as the quantitative expression of temperature threshold, when the lethality halves the survival of plant organs, buds or cells causing 50\% death rate. The damage is highly dependent on the temperature and on its duration (length of time), but not at least on the frost tolerance of the fruit trees. The incidence and severity of damage is analysed according to the apricot and peach varieties of their different susceptibility or tolerance too. Four fruit growing regions, two of the in Transdanubia and two belonging to the regions east of the Tisza river have been selected to trace the incidence and severity of frost damages. For that purpose, we analysed the history of the past 60 year period, 1951-2010, utilising the database of the network of 16 meteorological stations of the countrywide service.

Being aware of the values of $\mathrm{LT}_{50}$ during the rest period and afterward, the compulsory dormancy caused by low temperature, the number of days, the probability of frost damage could be predicted. The role of the orographical profile, the height above sea level and the exposition of plantations are also decisive. Within the same plantation, 20-30 m difference of level may cause large diversity in temperature and frost damage. Air circulation and regular incidence of winds within the Carpathian basin modify the occurrence and severity of damages. Lowlands near the southern and northern country borders are particularly exposed to winter frosts. Most damages are reported in February, as temperatures below $-20{ }^{\circ} \mathrm{C}$ especially if the first part of the winter was mild, or in January was a warm period. With the end of the physiological rest period of the trees, the frost-susceptibility increases significantly, and a cold period of $-15^{\circ} \mathrm{C}$ may cause heavy damage. This study proves that tolerance of varieties influence the damages substantially. By planting frost tolerant varieties, winter frost damages could be diminished by $40-50 \%$ at the same growing sites. Present results may also offer a tool to estimate the risk of frost damages and express the security of yields at a given site based on the data accumulated in the database over many years.
\end{abstract}

Key words: frost damage, fruit growing region, $\mathrm{LT}_{50}$, absolute minimum temperature, risk of frost, rest period, dormancy period, frost tolerance

\section{Introduction and survey of literature}

Winter frosts are the most important of risks fruit growing, therefore, its quantification is an important task. The measure of the damage is studied by the knowledge of physiological processes. During the physiological rest period, the trees are able to withstand $-20{ }^{\circ} \mathrm{C}$ frosts without damage, whereas after the rest period, the compulsory (temperature caused) dormancy, a $-15^{\circ} \mathrm{C}$ frost may cause near $100 \%$ frost damage (Proebsting, E. L. \& Mills, H. H., 1966). Based upon earlier results, we elaborated the $\mathrm{LT}_{50}$ function for apricot and peach varieties, and distinguished between three categories, as frost susceptible, medium toleerat and frost tolerant varieties. By means of the $\mathrm{LT}_{50}$ function, we may extend the study for all fruit varieties grown in Hungary. Apricots and peaches being the most threatened fruit species of Hungary, we present an example for the use of the function. Two Transdanubian and other two Trans-Tisza growing sites have been selected for the meteorological study, how we could calculate the probability of the damage at least on the $50 \%$ level. As by knowing the frequency of climatic risks would help to determine the risks of production. The growing sites and varieties of peach and apricot plantations have been thoroughly elaborated by Timon (2000), Zayan (1981) and Szalay (2001).

Our earlier studies stated that the variety Venus known to be extremely frost susceptible suffered heavy damages during the winter in the regions Szeged-Szatymaz at the Lake Balaton at the middle of January (probability 20-22\%), whereas at in the region Mecsekalja, the major frost damage occurred at a probability of $13-14 \%$ at the end of January (Lakatos et al., 2005a).

With the exception of Mecsekalja, the highest probability of winter frost damages is around the middle of January. For a frost tolerant peach variety, Redhaven, the critical period 
is between October 15 and April 1. In the region SzegedSzatymaz the risk of frost increased in mid of January (up to 16\%). At Mecsekalja, the beginning of February, around the Lake Balaton, the mid of February is most exposed to frosts. At the Mecsekalja, frosts do not endanger after beginning of March the variety Redhaven (Lakatos et al. (2005b).

As a susceptible variety, Ceglédi bíborkajszi, is an example to show maximum susceptibility (with 12-20\% probability) during the winter around the mid of January in the region Mátra-Bükkalja as well as around Buda (Lakatos et al. 2006 a). Between the rivers Duna-Tisza, the probability of frost damage is rather high (20\%) at the beginning of March. Similar conclusions are actual for the medium frost susceptible variety Babygold6 (Lakatos et al., 2006c). The probabilities referring to the whole winter period are less high, by 20-30\% than for the susceptible peach variety Venus. At the region Szeged-Szatymaz, the probability of frost damage on Babygold6 was 38\%. Redhaven, known as a frost tolerant variety suffered similar frost damage as the former two varieties, but for the whole winter period compared with the variety Venus, the probability of damage was reduced by 40-50\%. At the region Szeged-Szatymaz, the probability of frosts is $26 \%$ for Redhaven (Lakatos et al., 2006c).

A good, frost tolerant apricot variety, Bergeron, displayed changes in its probability of damage along the winter season between October 15 and April 1 (Lakatos et al., 2006b), as in the region of Mátra-Bükkalja, the probability of damage increased to $14 \%$ in the mid of January, whereas in the mid of February, it drops below the average of other regions. In the Duna-Tisza-köz region, the highest probability of frost damage occurs from mid of January to mid of February and in early March, whereas around Buda, most risk of damage is in end of February. After the mid of March in the region around Buda, no frost danger is threatening any more on the variety Bergeron, whereas in regions Mátra-Bükkalja and Duna-Balaton, the probability of damages still is $4-6 \%$ in the mid of March.

Looking for the distribution of damages at growing sites and apricot varieties in question, the probability of winter frost damage was the highest in the region Duna-Tisza köze, next in Mátra-Bükkalja, followed by Pest-Gödöllő region (Szabó et al., 2006). The less danger of frost was for apricots in the environ Buda among the 5 sites analysed.

Probabilities of winter frost damages in peaches show highest frequency in Szeged-Szatymaz, the next frequency at the Balaton region followed by Debrecen region. Less endangered among 6 regions proved to be Mecsekalja.

\section{Material and method}

Observations regarding the performance (susceptibilitytolerance) of buds and reproductive organs during the rest period are made by Szalay et al. (2000) and Szalay (2001), and he adapted to Hungarian relations the calculations developed for the estimation of chilling requirement of fruit trees.
The $\mathrm{LT}_{50}$ function shows the temperature, which causes $50 \%$ death of flower buds. Determination of this value is based on the physiological observations of buds (Horn E., 1956) and a freezing experiment is started for that purpose (Horn E., 1965).

Our initiative used the database of $\mathrm{LT}_{50}$ values raised by Szabó et al. (2001) and Szalay et al. (2000). At three growing sites (Siófok, Szigetcsép, Pomáz) during the period 1995-2004, 9 peach varieties (Venus, Red June, Babygold6, Redhaven, Mayfire, Caldesi, Early Redhaven, Champion, and Piroska) as well as 5 apricots (Ceglédi bíbor, Ceglédi óriás, Gönci magyar kajszi, Mandula kajszi, Bergeron) were analysed for frost tolerance. Thus, the above mentioned varieties were tested for their cold tolerance expressed by the $\mathrm{LT}_{50}$ function.

The database of 4 fruit growing regions was used for the period 1951-2010, i.e. 60 years.

The four regions are:

- Debrecen

- Nagykanizsa

- Siófok

- Újfehértó

The data used were the daily minimum temperatures. The Countrywide Meteorological Service (OMSZ) has 16 stations in Hungary. The data were processed for variance analysis, probabilities and frequencies fitting to the curves of regression. For that purpose we used the Excel program.

A Data collected on three growing sites, 9 peach- and 5 apricot varieties, $\mathrm{LT}_{50}$ values developed during the last 8 years, served as a basis for express the temporary changes between October 15 and April 1 for all sites, varieties and years. The $\mathrm{LT}_{50}$ values obtained were subject to variance analysis and the coefficients of variances $(\mathrm{CV})$ are computed for each apricot variety (Figure 1) and peach variety (Figure $2)$. According to the variety specific CV (\%) values, we could distinguish poorly frost tolerant, medium tolerant and tolerant varieties. Our hypothesis was that the $\mathrm{LT}_{50}$ values of the frost tolerant varieties have lower (yearly) variability than the susceptible varieties.

The cold tolerance expressed by a polynomial function of the $2^{\text {nd }}$ grade fitted most to the data measured:

$$
y=a x^{2}+b x+c
$$

The coefficients of the best fitting function express the differences displayed by frost tolerant, medium tolerant and poorly tolerant varieties.

The $\mathrm{LT}_{50}$ function during the rest period is a parameter of frost susceptibility or tolerance. If we find during the observed period temperatures corresponding or lower than the $\mathrm{LT}_{50}$ function of the variety in question, winter frost damage was expected. Apricot varieties of different frost tolerance show the largest differences of their $\mathrm{LT}_{50}$ values at the end of their rest period, which means at the same time that apricot trees are more susceptible to frost at the end of the or at the beginning of spring, than earlier (autumn or first half of winter) (Figure 3). 


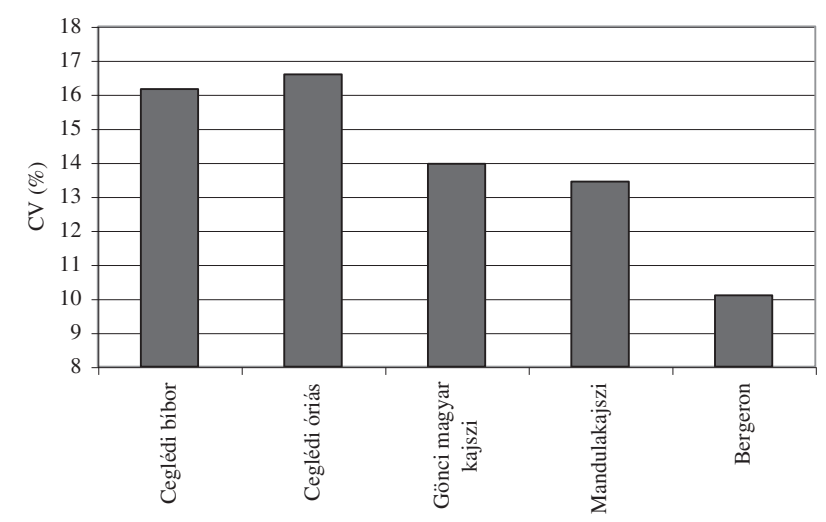

Figure 1 - Coefficients of variation (CV\%) of the yearly LT50 values of the five apricot varieties

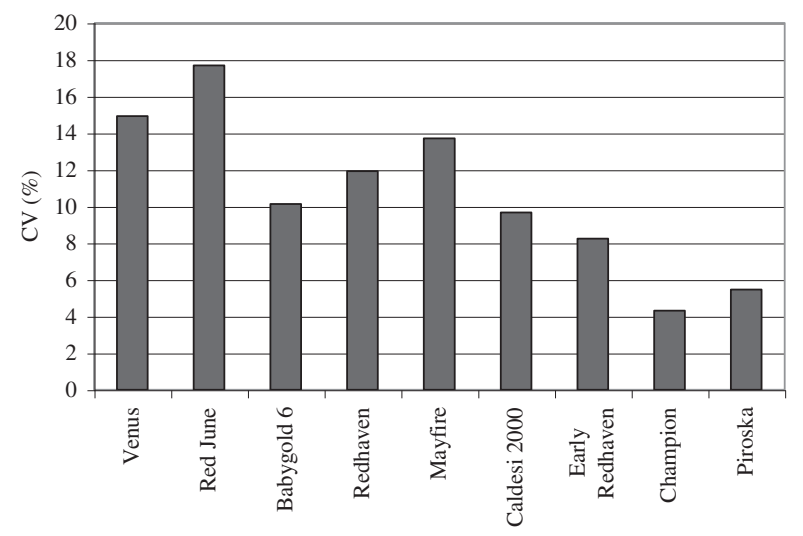

Figure 2 - Coefficients of variation (CV\%) of the yearly LT50 values of the 9 peach varieties

Peach performs differently from the apricot: it suffers also from the frosts during the late autumn or early winter (Figure 4). Poorly tolerant peach varieties are particularly susceptible to low temperatures of a cold early winter weather.

\section{Results}

If we observe the distribution of the excessive minimum temperatures of the winter season in Hungary, it is evident that the spatial differences of the absolute maxima decrease on the country's area, but their heterogeneity increases (Figure 5). As an effect of air circulations, the cold Polar and Siberian air approaches the Carpathian basin from NE across the northern mountains and their passes, and/or from the southern valley of the Danube. During the winter, however, the main wind carries mild Oceanic air from NW and warm Mediterranean air from SW. That is the reason of the lowest winter minima, which occur in the NE and SE region of the country east of the Tisza river, whereas the highest absolute minima were measured in Transdanubia, on the southern and NW corner of the country according to the 60 year long period. The mean absolute minima were about by $2^{\circ} \mathrm{C}$ higher in Transdanubia than east of the Tisza.

As for the temporal changes, the values of excessive temperatures show clearly an increment during the last

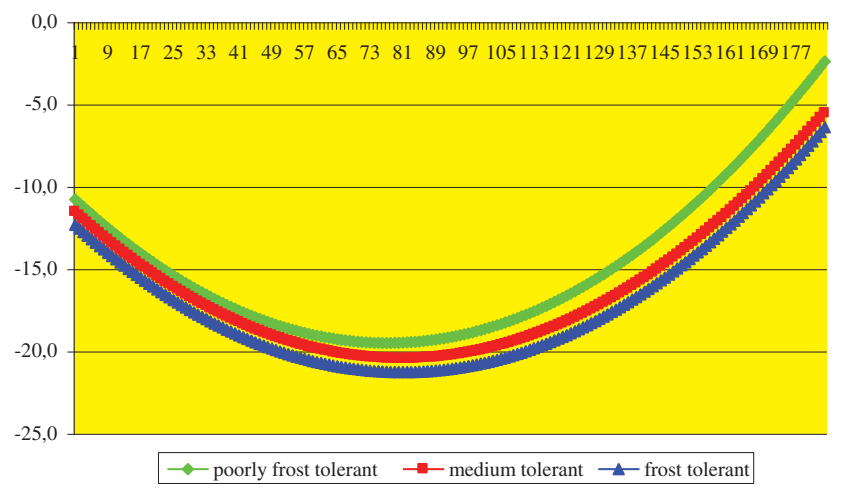

Figure 3 - Changes of the LT50 values in apricot trees during the rest period

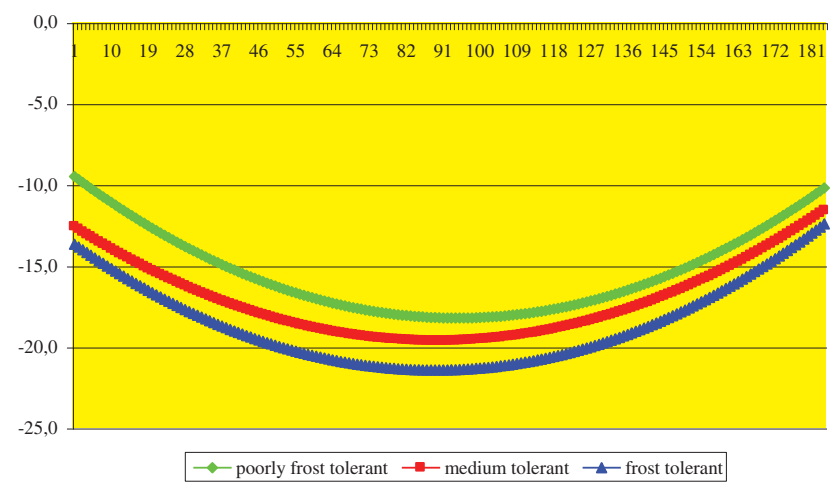

Figure 4 - Changes of LT50 values during the rest period of peach trees

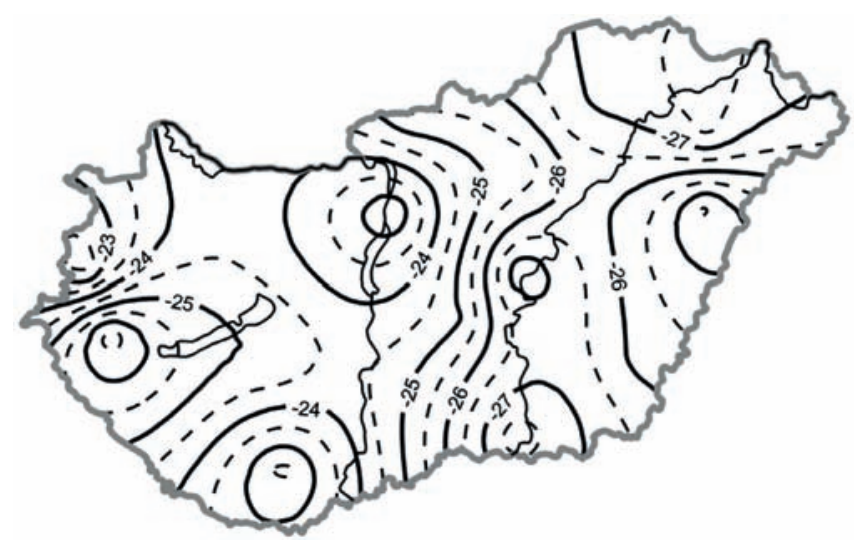

Figure 5 - The spatial distribution the mean absolute minima of the winter season in Hungary measured at 16 meteorological stations over the period 1951-2010.

2 decennia almost at every region (Figure 6). The reason of it is that during a period of the 1980-es particularly low temperatures occurred mainly around Debrecen. We cannot state, however, that the global warming up will protect us from excessive minima in the future, and the probability of hard winters will diminish.

If we consider the mean temperature of the rest period, and analyse the temperature at four sites and through 60 years, we may propose the following statements: Until 
the end of 1980-es, two East-Hungarian regions proved to be the most cold (Figure 7). Beginning with the 1990-es, the region of Nagykanizsa warmed up much less intensely than the rest of stations. Then station at Siófok showed the highest mean temperatures during the rest period. Out of the 60 years, the decennium of the 1960-es was the sole with a mean temperature below zero during the rest period. The higher and less variable temperatures of the

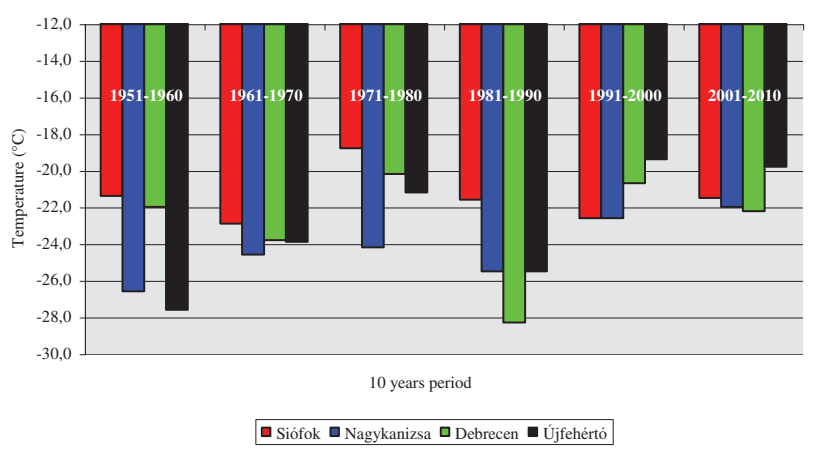

Figure 6 - The occurrence of absolute winter minima during ten-yearslong periods (decennia) at four regions over the last sixty years 1951-2010.

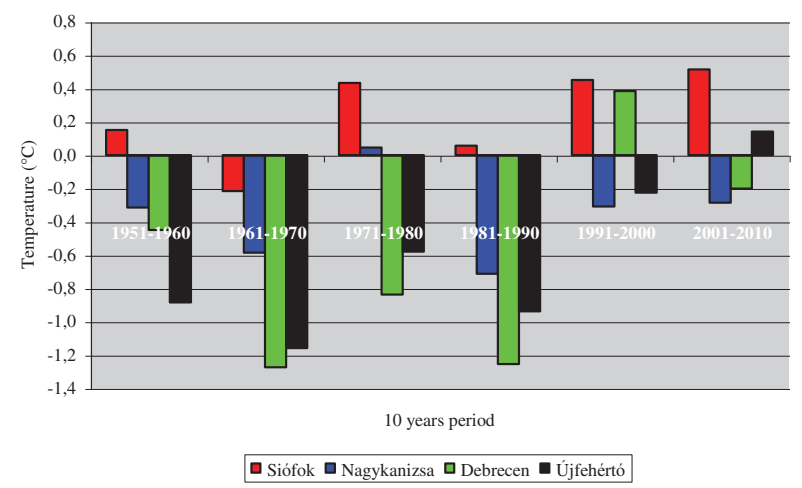

Figure 7 - The change of the mean minimum temperatures over the 10 -year-long periods (decennia) during the rest period (October $1 \div \mathrm{March}$ $31)$ at 4 regions between 1951-2010.

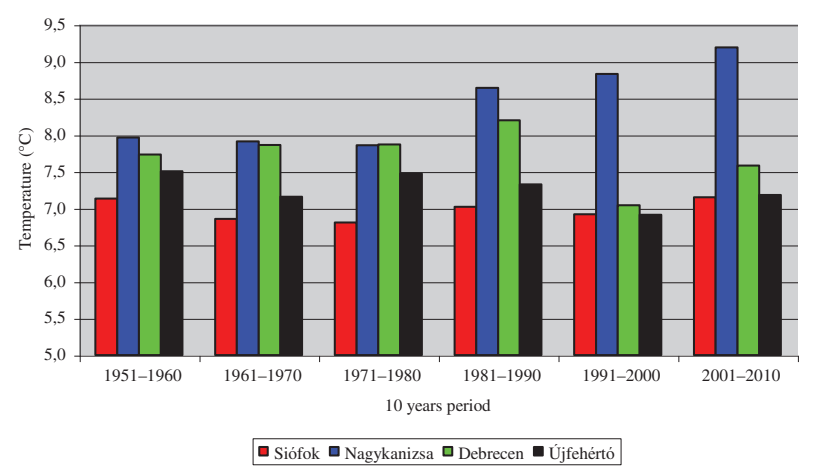

Figure 8 - The mean variation of temperature during the rest period (October 1 - March 31) over the 10-year-long periods (decennia) at 4 regions between 1951-2010. station is due to the compensating (heating) effect of the water: Lake Balaton.

The meaning of the frost risk during the rest period is highly dependent on the weather before the appearance of low temperatures. Changes of larger amplitude occur mainly during a calm night. The duration of frost may be short, but its effect serious. Regarding the daily mean temperatures on the 4 regions, the daily variation shows differences. In Figure 8 , we sea clearly that while no change is found during 60 years at Siófok, the daily variation of temperature increased beginning with the 1970-es at Nagykanizsa, which means an increased risk of winter frosts. At the same time, at Debrecen and Újfehértó, the variation of temperature seems to be more moderated.

Apricot plantations are more susceptible to winter frosts than peach plantations. On the example of apricots, we will prove at the 4 regions examined the differences between the two fruit species regarding the probability of frost damages. If we observe the probability of winter frost damages during the rest period in frost susceptible apricot varieties, we will state:

In spite of the fact that the coldest period of the winter is the mid of January, the probability of frost damage varies between regions over $2-6 \%$. The damages appear during the month February. The less winter frost damage is registered at Siófok (Figure 9a). On this growing site, where during January, the probability of frost causing more than $50 \%$ damage was less than $2 \%$. Means of many years prove that the highest risks $(6.7 \%)$ are expected at February 9. During the rest period ó, we find 7 days only, when the climatic frost damage attained the 5\% rate. After March 19, we may become confident of getting free from risks as a single day occurred only with $5 \%$ damage. This extraordinarily favourable condition is entirely due to the proximity of the Lake Balaton. The meteorological station is on the shore of the Lake, the night temperature is largely moderated by the mass of water. Its effect is especially expressed by the night temperature minima.

The most severe winter frost damages (12.9\%) occurred with the highest probability at Debrecen out of the 4 regions compared (Figure 9b). While the most risky climatic period of frost damages is the first part of the February at Siófok, this at

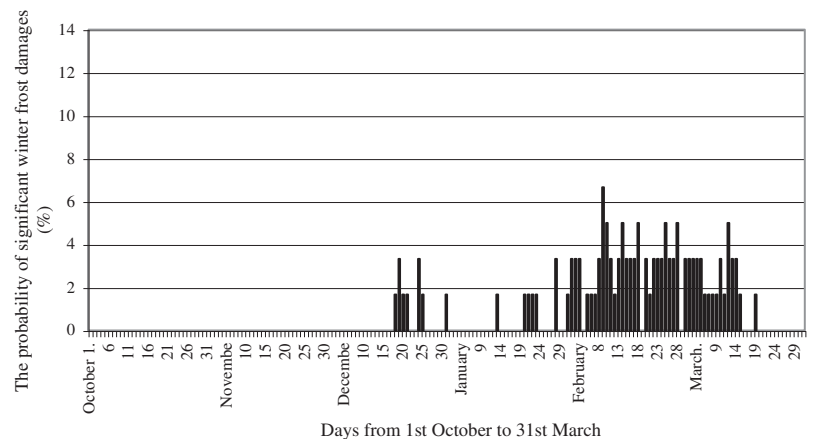

Figure $9 \mathrm{a}-$ The probability of significant winter frost damages on frost susceptible apricot varieties (Siófok, 1951-2010). 


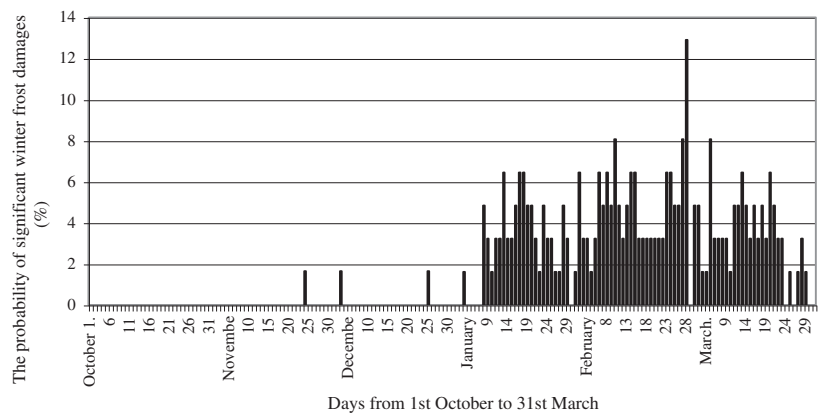

Figure $\mathbf{9 b}$ - The probability of significant winter frost damages in susceptible apricot varieties (Debrecen-Pallag, 1951-2012)

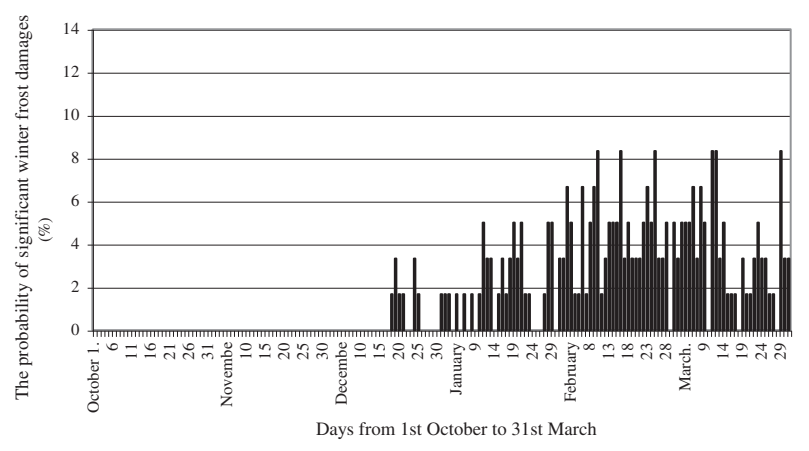

Figure $9 c$-The probability of significant winter frost damages on frost susceptible apricot varieties (Nagykanizsa,1951-2012)

Debrecen ensues later around the end of February 28. Significant, up to $8 \%$ going frost damages are expected over 4 days, which did not occur at Siófok, at all, during the 60 years. During the rest period, 36 risky days occurred with a five times higher frequency than at Siófok, as the climatic frost attains 5\%.

Although highest value of the frost occurrence is less at the Nagykanizsa cultivation area in Debrecen the frequency and length of frost is almost same as in Debrecen. At the Nagykanizsa cultivation area we can accept 6 days when the frost probability reaches the eight percent during the rest period (Figure 9c). During the rest period at 34 days occurs that the climatic frost damage reaches five percent. While at the cultivation area of Debrecen after $21^{\text {st }}$ March we can not accept serious, bigger than five percent frost damage at the cultivation area of Nagykanizsa even $29^{\text {th }}$ March we can get more than eight percent climatic frost probability. This is an extremely high risk of cultivation because in this cultivation area the blooming time starts earlier than the other places of country.

Despite of the cultivation area of Újfehérto it is not far from Debrecen during the rest period we can find significant differences between the distributions of frost damage. At the Újfehértó cultivation area during the rest period only two days we can get significant, (more than eight percent) frost damage (Figure 9d). During the rest period 24 days occurs at least $5 \%$ climatic probability of frost damage.

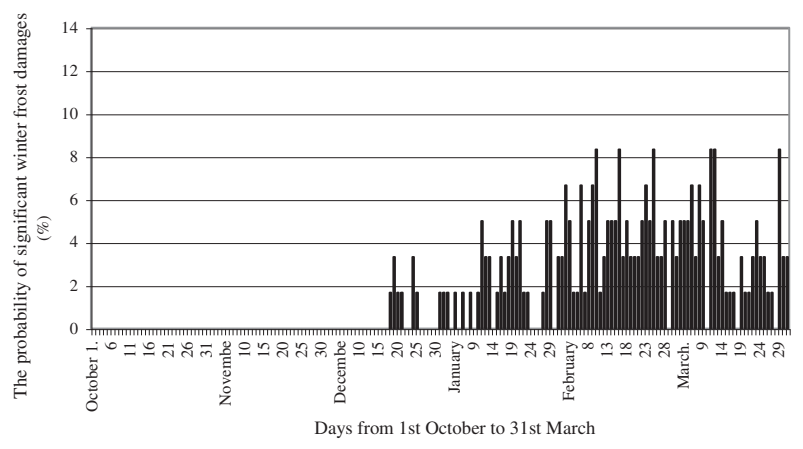

Figure $9 \boldsymbol{c}$-The probability of significant winter frost damages on frost susceptible apricot varieties (Nagykanizsa,1951-2012)

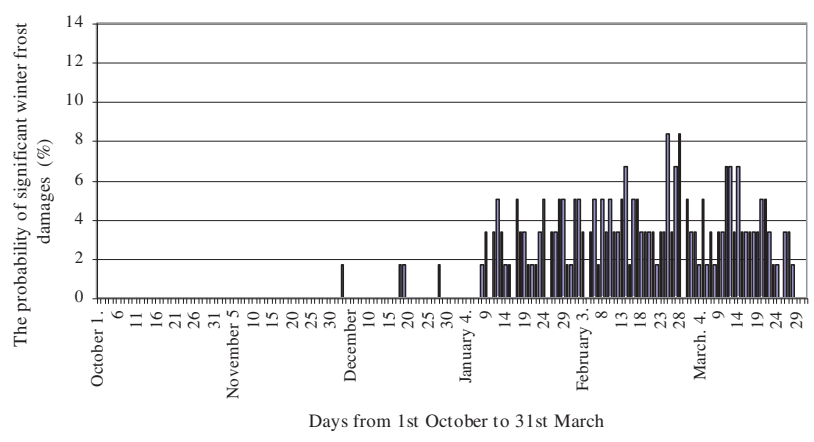

Figure $9 \boldsymbol{d}$-The probability of significant winter frost damages on frost susceptible apricot varieties (Újfehértó, 1951-2012]

Table 1 - The parameters of the LT50 function in apricot and peach varieties of different susceptibility/tolerance to frost

\begin{tabular}{|c|c|c|c|c|c|c|}
\hline & \multicolumn{3}{|c|}{ apricot } & \multicolumn{3}{c|}{ peach } \\
\hline & $\begin{array}{c}\text { Frost } \\
\text { susceptible }\end{array}$ & $\begin{array}{l}\text { Medium } \\
\text { tolerant }\end{array}$ & Tolerant & $\begin{array}{c}\text { Frost } \\
\text { susceptible }\end{array}$ & $\begin{array}{c}\text { Medium } \\
\text { tolerant }\end{array}$ & Tolerant \\
\hline A & 0.0015 & 0.0014 & 0.0014 & 0.001 & 0.0009 & 0.001 \\
\hline B & -0.2317 & -0.2262 & -0.2266 & -0.1889 & -0.161 & -0.1782 \\
\hline C & -10.568 & -11.328 & -12.113 & -9.2956 & -12.421 & -13.481 \\
\hline
\end{tabular}

Our studies proved that the probability of damages caused by climatic frosts changed a lot if frost tolerant fruit varieties are considered instead of susceptible ones at the dame growing site. In Table 2, the comparison allows the interpretation of this fact at Siofok, where during the rest period, susceptible

Table 2 - The probability of climatic frost damages during the rest period for susceptible and tolerant apricot and peach varieties at Siófok (1951-2010)

\begin{tabular}{|l|l|c|c|c|c|c|c|}
\hline \multicolumn{3}{|c|}{ apricot } & \multicolumn{3}{c|}{ peach } \\
\hline & $\begin{array}{c}\text { Frost } \\
\text { susceptible }\end{array}$ & $\begin{array}{l}\text { Medium } \\
\text { tolerant }\end{array}$ & Tolerant & $\begin{array}{c}\text { Frost } \\
\text { susceptible }\end{array}$ & $\begin{array}{c}\text { Medium } \\
\text { tolerant }\end{array}$ & Tolerant \\
\hline Siófok & $\begin{array}{l}5 \% \text { damage } \\
\text { (day) }\end{array}$ & 7 & 1 & 1 & 1 & 0 & 0 \\
\hline Siófok & $\begin{array}{l}8 \% \text { damage } \\
(\text { day })\end{array}$ & 0 & 0 & 0 & 0 & 0 & 0 \\
\hline Siófok & $\begin{array}{l}\text { max damage } \\
(\%)\end{array}$ & 6.7 & 5.0 & 5.0 & 5.0 & 3.3 & 3.3 \\
\hline
\end{tabular}


apricot varieties were exposed to damages of more than $5 \%$ losses for 7 days yearly as a mean of many years, whereas in frost tolerant apricot varieties, the probability of damages of $5 \%$ losses were reduced to a single day.

In the fruit growing region of Debrecen, the difference between the probability of frost damages on frost susceptible and tolerant varieties was conspicuous (Table 3). Frost susceptible apricot varieties are exposed yearly during 36 days to damages causing $5 \%$ losses at least, whereas frost

Table 3 -The probability of climatic frost damages during the rest period for susceptible and tolerant apricot and peach varieties at Debrecen (1951-2010)

\begin{tabular}{|l|l|c|c|c|c|c|c|}
\hline \multicolumn{2}{|c|}{ apricot } & \multicolumn{3}{c|}{ peach } \\
\hline & $\begin{array}{c}\text { Frost } \\
\text { susceptible }\end{array}$ & $\begin{array}{c}\text { Medium } \\
\text { tolerant }\end{array}$ & $\begin{array}{c}\text { Frost } \\
\text { susceptible }\end{array}$ & $\begin{array}{c}\text { Medium } \\
\text { tolerant }\end{array}$ & $\begin{array}{c}\text { Frost } \\
\text { susceptible }\end{array}$ & $\begin{array}{c}\text { Medium } \\
\text { tolerant }\end{array}$ \\
\hline Debrecen & $\begin{array}{l}5 \% \\
\text { damage } \\
\text { (day) }\end{array}$ & 36 & 12 & 7 & 15 & 3 & 0 \\
\hline Debrecen & $\begin{array}{l}8 \% \\
\text { damage } \\
(\text { day })\end{array}$ & 4 & 0 & 0 & 0 & 0 & 0 \\
\hline $\begin{array}{l}\text { max } \\
\text { damage } \\
(\%)\end{array}$ & 12.9 & 6.5 & 4.8 & 6.5 & 6.5 & 3.2 \\
\hline
\end{tabular}

Table 4 - The probability of climatic frost damages during the rest period for susceptible and tolerant apricot and peach varieties at Nagykanizsa (1951-2010)

\begin{tabular}{|l|l|c|c|c|c|c|c|}
\hline \multicolumn{2}{|c|}{} & $\begin{array}{c}\text { Frost } \\
\text { susceptible }\end{array}$ & $\begin{array}{c}\text { Medium } \\
\text { tolerant }\end{array}$ & $\begin{array}{c}\text { Frost } \\
\text { tolerant }\end{array}$ & $\begin{array}{c}\text { Frost } \\
\text { susceptible }\end{array}$ & $\begin{array}{c}\text { Medium } \\
\text { tolerant }\end{array}$ & $\begin{array}{c}\text { Frost } \\
\text { tolerant }\end{array}$ \\
\hline Nagykanizsa & $\begin{array}{l}5 \% \\
\text { damage } \\
\text { (day) }\end{array}$ & 33 & 11 & 6 & 15 & 3 & 0 \\
\hline Nagykanizsa & $\begin{array}{l}8 \% \\
\text { damage } \\
(\text { day })\end{array}$ & 6 & 1 & 1 & 1 & 0 & 0 \\
\hline Nagykanizsa & $\begin{array}{l}\text { max } \\
\text { damage } \\
(\%)\end{array}$ & 8.3 & 8.3 & 8.3 & 8.3 & 6.7 & 3.3 \\
\hline
\end{tabular}

Table 5 - The probability of climatic frost damages during the rest period for susceptible and tolerant apricot and peach varieties at Újfehértó (1951-2010)

\begin{tabular}{|l|l|c|c|c|c|c|c|}
\hline \multicolumn{3}{|c|}{ Apricot } & \multicolumn{3}{c|}{ peach } \\
\hline & $\begin{array}{c}\text { Frost } \\
\text { susceptible }\end{array}$ & $\begin{array}{c}\text { Medium } \\
\text { tolerant }\end{array}$ & $\begin{array}{c}\text { Frost } \\
\text { tolerant }\end{array}$ & $\begin{array}{c}\text { Frost } \\
\text { susceptible }\end{array}$ & $\begin{array}{c}\text { Medium } \\
\text { tolerant }\end{array}$ & $\begin{array}{c}\text { Frost } \\
\text { tolerant }\end{array}$ \\
\hline Újfehértó & $\begin{array}{l}5 \% \\
\text { damage } \\
(\text { day })\end{array}$ & 24 & 1 & 1 & 3 & 0 & 0 \\
\hline Újfehértó & $\begin{array}{l}8 \% \\
\text { damage } \\
(\text { day })\end{array}$ & 2 & 0 & 0 & 0 & 0 & 0 \\
\hline Újfehértó & $\begin{array}{l}\text { max } \\
\text { damage } \\
(\%)\end{array}$ & 8.3 & 5.0 & 5.0 & 5.0 & 3.3 & 3.3 \\
\hline
\end{tabular}

tolerant varieties are at the same conditions for a 7-day-long period exposed to similar, 5\% losses. The same phenomena are experienced with susceptible and tolerant peach varieties, where instead of 15 days per year are probably afflicted the susceptible varieties and not a single day during the 60 years the tolerant varieties where the threshold was 5\% losses.

As earlier stated, in the region of Nagykanizsa, the probability of climatic frost causing $5 \%$ damages is somewhat lower than at Debrecen, but the number of days was higher than in the regions east to the Tisza, when the probability of damage was higher than $8 \%$ (Table 4). For frost susceptible apricot varieties, 33 days of the rest period are threatened by frost causing at least $5 \%$ damage, whereas for tolerant varieties the threatened period means 6 days only. For frost susceptible peach varieties, 15 days of the rest period are threatened, whereas the risk for tolerant varieties diminishes the probability to zero days, when up to $5 \%$ damages were expected.

The region of Újfehértó is north to Debrecen, in spite of that its climatic properties are more favourable than its southern neighbour. Susceptible apricot varieties are exposed during the rest period for 24 days to the probability of frosts causing more than 5\% damage, whereas frost tolerant varieties, this risk is reduced to 1 day only. Susceptible peach varieties are less endangered, as 3 days are probably risked by frosts causing more than 5\% damage. Frost tolerant varieties are not risked according to the 60 year long period of observations.

If we analyse the probability of heavy or more than $50 \%$ damage causing frosts during the rest period and their distribution in the 10-year-long periods (decennia), the following conclusions are actual:

For frost susceptible apricot varieties, the less risky growing site is Siófok out of the 4 regions studied. Significant frost damages are expected there in each $3^{\text {rd }}$ year (Table $6)$. The highest risks of winter frosts are threatening the susceptible apricot varieties in the region of Nagykanizsa. As far as the climatic conditions do not change, in 7 years out of 10 the trees will suffer from winter frost damages.

The region of Újfehértó represents less risks of winter frosts than the neighbouring region of Debrecen. Both fruit growing regions are expecting frost damages in 6 years out of 10 .

For susceptible peach varieties, the highest safety is found in the region of Siófok, where the risk of winter frosts is expected in 3 years 
Table 6 - The probability of significant winter frost damages, and its distribution over the last 6 decennia for frost susceptible apricot and peach varieties in 4 regions (1951-2010)

\begin{tabular}{|c|c|c|c|c|c|c|c|c|}
\hline \multicolumn{9}{|c|}{ Frost susceptible } \\
\hline & \multicolumn{4}{|c|}{ Apricot } & \multicolumn{4}{|c|}{ Peach } \\
\hline & Debrecen & Nagykanizsa & Siófok & Újfehértó & Debrecen & Nagykanizsa & Siófok & Újfehértó \\
\hline $1951-1960$ & 6 & 9 & 4 & 4 & 3 & 6 & 3 & 3 \\
\hline $1961-1970$ & 10 & 9 & 5 & 8 & 8 & 8 & 3 & 4 \\
\hline 1971-1980 & 7 & 3 & 2 & 6 & 6 & 4 & 1 & 4 \\
\hline 1981-1990 & 7 & 5 & 3 & 6 & 6 & 5 & 4 & 5 \\
\hline $1991-2000$ & 3 & 7 & 2 & 6 & 2 & 3 & 2 & 2 \\
\hline $2001-2010$ & 4 & 8 & 5 & 4 & 4 & 5 & 5 & 3 \\
\hline mean & 6.2 & 6.8 & 3.5 & 5.7 & 4.8 & 5.2 & 3.0 & 3.5 \\
\hline
\end{tabular}

Table 7 - The probability of significant winter frost damages, and their distribution over the last 6 decennia for medium frost tolerant apricot and peach varieties in 4 regions (1951-2010)

\begin{tabular}{|c|c|c|c|c|c|c|c|c|}
\hline \multicolumn{9}{|c|}{ Medium frost tolerant } \\
\hline & \multicolumn{4}{|c|}{ Apricot } & \multicolumn{4}{|c|}{ Peach } \\
\hline & Debrecen & Nagykanizsa & Siófok & Újfehértó & Debrecen & Nagykanizsa & Siófok & Újfehértó \\
\hline $1951-1960$ & 3 & 6 & 3 & 4 & 2 & 5 & 3 & 3 \\
\hline $1961-1970$ & 8 & 7 & 1 & 6 & 7 & 6 & 1 & 2 \\
\hline $1971-1980$ & 3 & 3 & 1 & 4 & 4 & 2 & 0 & 1 \\
\hline $1981-1990$ & 5 & 4 & 3 & 4 & 4 & 3 & 3 & 3 \\
\hline $1991-2000$ & 2 & 4 & 1 & 0 & 2 & 1 & 1 & 0 \\
\hline 2001-2010 & 3 & 4 & 3 & 3 & 2 & 5 & 4 & 3 \\
\hline mean & 4.0 & 4.7 & 2.0 & 3.5 & 3.5 & 3.7 & 2.0 & 2.0 \\
\hline
\end{tabular}

out of 10. It is not a surprise that the most risky growing site was the region of Nagykanizsa out of the 4 regions observed for susceptible peach varieties, where every second year is threatened by winter frosts. At Újfehértó, every $3^{\text {rd }}$ year is endangered, whereas every second in the region Debrecen according to the statistics traced over 60 years.

For medium frost tolerant apricot varieties, the most recommended growing sites are the regions of Siófok and of Újfehértó out of 4 sites, where the winter frost damages appear in every $5^{\text {th }}$ year (Table 7 ), whereas the highest risks appeared at Nagykanizsa, i.e. in every second year over the 60 year long period. At Újfehértó, conditions are better than at Debrecen. But the probability of losses caused by frosts is expected in 3-4 years out of 10 at both regions.

Peach varieties of medium frost tolerance are grown most safely in the region of Siófok. In 2 years out of 10, frost damage is expected. The less favourable growing site is Nagykanizsa out of 4 observed ones, where frosts are forecasted in 4 years out of 10 .

For frost tolerant apricot varieties, also the region of Siófok is the safest growing site out of the 4 examined. Significant damages caused by frost are expected each $5^{\text {th }}$ year (Table 8). As most risky site, on the other hand, also Nagykanizsa is considered, where frost damages are suspected in 4 years, out of 10. The Újfehértó and Debrecen regions threaten with notable winter frosts in every $3^{\text {rd }}$ year, but once out of 10 years heavy frost damages may occur. Nagykanizsa and Debrecen represent those sites, where for frost tolerant peach varieties the conditions are less favourable out of the 4 sites examined. Every $5^{\text {th }}$ year may withstand heavy winter frost damages.

For the winter season, the altitude of the growing site above sea level is a decisive component of the environment. Cold air is moving and accumulating always to the lowest points of the profile of landscape, where the low temperature may stay during a longer time, which becomes often deleterious for the buds of fruit trees. During the last rest period, early February was the coldest period of winter. This alone means a risk when the frost tolerance of trees diminishes notably. The values of the $\mathrm{LT}_{50}$ function show it clearly, but the risk is aggravated much by the fact that the mean temperatures of the previous months, December and January, were higher by $2{ }^{\circ} \mathrm{C}$ than the means of many years (1971-2000). The early blooming trees ended their (deep) rest period, which means that their susceptibility increased substantially, while their budding is inhibited by the low temperature (obligate 
Table 8 - The probability of significant winter frost damages and their distribution over the last 6 decennia for frost tolerant apricot and peach varieties in the 4 regions examined (1951-2010)

\begin{tabular}{|c|c|c|c|c|c|c|c|c|}
\hline \multicolumn{9}{|c|}{ Frost tolerant } \\
\hline & \multicolumn{4}{|c|}{ Apricot } & \multicolumn{4}{|c|}{ Peach } \\
\hline & Debrecen & Nagykanizsa & Siófok & Újfehértó & Debrecen & Nagykanizsa & Siófok & Újfehértó \\
\hline $1951-1960$ & 2 & 6 & 3 & 3 & 2 & 3 & 2 & 3 \\
\hline $1961-1970$ & 6 & 5 & 1 & 4 & 4 & 3 & 1 & 2 \\
\hline 1971-1980 & 3 & 3 & 1 & 3 & 0 & 2 & 0 & 1 \\
\hline 1981-1990 & 5 & 4 & 3 & 4 & 3 & 3 & 2 & 2 \\
\hline 1991-2000 & 2 & 2 & 1 & 0 & 0 & 1 & 1 & 0 \\
\hline 2001-2010 & 2 & 2 & 2 & 3 & 2 & 1 & 1 & 0 \\
\hline mean & 3.3 & 3.7 & 1.8 & 2.8 & 1.8 & 2.2 & 1.2 & 1.3 \\
\hline
\end{tabular}

Table 9 - Temperatures read in the regions of Northern Great Plain, Rétköz, Bereg county and Nyírség between February 10-13 at dawn

\begin{tabular}{|l|c|c|c|c|}
\hline & $\begin{array}{c}\text { Nyíregyháza- } \\
\text { Napkor }\end{array}$ & $\begin{array}{c}\text { Lövópetri } \\
\text { 'Szőlöhegy" } \\
\text { hilltop }\end{array}$ & $\begin{array}{c}\text { Lövöpetri } \\
\text { 'Szölöhegy" } \\
\text { valley }\end{array}$ & $\begin{array}{c}\text { Vásáros- } \\
\text { namény }\end{array}$ \\
\hline Geographic latitude & 47.96 & 48.00 & 48.10 & 48.13 \\
\hline Geographic longitude & 21.88 & 22.20 & 22.10 & 22.31 \\
\hline $\begin{array}{l}\text { Altitude above sea level } \\
(\mathrm{m})\end{array}$ & 142 & 136 & 120 & 123 \\
\hline $\begin{array}{l}\text { Minimum temperature }\left({ }^{\circ} \mathrm{C}\right) \\
2012.02 .10\end{array}$ & -14.4 & -18.5 & -23.0 & -22.2 \\
\hline $\begin{array}{l}\text { Minimum temperature }\left({ }^{\circ} \mathrm{C}\right) \\
2012.02 .11\end{array}$ & -14.4 & -17.0 & -19.5 & -19.5 \\
\hline $\begin{array}{l}\text { Minimum temperature }\left({ }^{\circ} \mathrm{C}\right) \\
2012.02 .12\end{array}$ & -13.9 & -16.0 & -18.0 & -18.9 \\
\hline $\begin{array}{l}\text { Minimum temperature }\left({ }^{\circ} \mathrm{C}\right) \\
2012.02 .13\end{array}$ & -9.6 & -11.5 & -14.5 & -9.8 \\
\hline
\end{tabular}

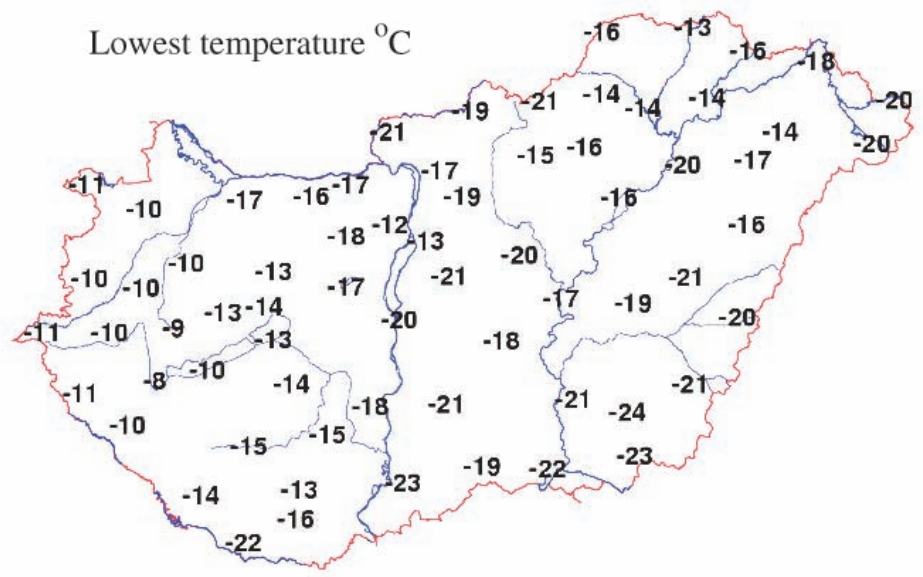

Figure 10 - The minimum temperatures read at the coldest dawn of the winter in Hungary at 2012 February 10 (source: daily report of the OMSZ) dormancy). If we look at the temperatures of the last winter season, especially the records of the coldest dawn of the year, we will see anomalies (Figure 10). In spite of the snow cover $(10-30 \mathrm{~cm})$ readings showed notable differences between measuring points not far from each other at different altitudes but also on the same level. Moreover, in the range of Szabolcs-Szatmár-Bereg counties, where the altitude varies over a $60-70 \mathrm{~km}$ space between $40-50 \mathrm{~m}$ only, nevertheless temperatures varied within more than $6^{\circ} \mathrm{C}$ amplitude. The date was February 10, 1012.

If we looked to readings of higher density than the 16 stations of the OMSZ, it turned out that sometimes $200 \mathrm{~m}$ distance may produce $4.5^{\circ} \mathrm{C}$ differences due to $16 \mathrm{~m}$ differences in altitude (Table 9).

\section{Conclusions}

By the use of the $\mathrm{LT}_{50}$ function, we are able to identify the days, when the low temperatures may risk frost damage on the trees during the rest period as well as during the obligate dormancy. From the database of a 60 year long period we may conclude to the probability of frost damages at the date of the year as well as of the locality, where records have been made. However, the severity of damages cannot be quantified by this method. The study presented does not consider the development of absolute minima, the history of cooling down and warming up periods.

The results, on the contrary, are used successfully for the estimation of risks for frost susceptible apricot and peach varieties, moreover, the differences between 
susceptible and frost tolerant varieties at the individual fruit growing regions examined. Recommendations of varieties for particular growing sites could be based on the data published, and the probability of risks being determined as the security of yields.

\section{Acknowledgement}

This study is funded by TECH_08-A3/2-2008-0373 and TECH_08-A4/2-2008-0138 projects.

\section{Literature used}

Horn E. (1956): Kajszibarackfák rügypusztulása. Biológiai Közlemények. 4 (1): 61-65.

Horn E. (1965): Télállóság és fagytürőképesség vizsgálata egyes őszibarackfajtáknál. Kertészeti és Szőlészeti Főiskola Közleményei. 29: 121-133.

Lakatos L., Szabó Z., Szalai L., Nyéki J., Racskó J. \& Soltész M. (2005a): A téli és tavaszi fagykárok gyakoriságának valószínűsége Magyarországi őszibarack termőtájakon. „Agro-21” Füzetek, 39: 102-113.

Lakatos L., Szabó Z., Szalai L., Soltész M., Racskó J. \& Nyéki J. (2005b): Az őszibarack téli fagytűrését jellemző számítási módszer. „Agro-21” Füzetek, 39: 17-35.

Lakatos L., Szalay L., Szabó Z., Nyéki J., Racskó J. \& Soltész M. (2006)a: A téli és tavaszi fagykárok előfordulási valószínűsége a főbb magyarországi kajszibarack termőtájakon. „Agro 21” Füzetek, 45: 172-185.
Lakatos L., Szalay L., Szabó Z., Soltész M., Racskó J. \& Nyéki J. (2006)b: A kajszi téli fagytűrését jellemző számítási módszer. „Agro 21” Füzetek, 45: 186-197.

Lakatos, L., Szabó, Z., Szalay, L., Soltész, M. \& Nyéki, J. (2006c): Calculation of climatic probability of winter and spring frost damages in the main peach and apricot growing districts of Hungary International Journal of Horticultural Science, 12. (2): 99-106

Mohácsy M.-Maliga P. \& ifj. Mohácsy M. (1959): Az őszibarack. Mezőgazdasági Kiadó, Budapest.

Proebsting, E. L. \& Mills, H. H. (1966): A standardized temperature-survival curve for dormant Elberta peach fruit buds. Proc. Amer. Soc. Hort. Sci. 103. (6): 842-845.

Szabó Z. (2002): Csonthéjas gyümölcsủek termésbiztonságának egyes tényezői. Akadémiai Doktori Értekezés, MTA, Budapest (Manuscript).

Szabó Z.-Szalay L. \& Papp J. (2001): Connection between the developmental stage and the cold hardiness of flower buds of peach varieties. V. International Peach Symposium. July 8-11. Davis, Ca (USA), Abstracts, Poster

Szabó Zoltán, Nyéki József, Racskó József, Lakatos László, Harsányi Gergely \& Soltész Miklós (2006): Téli és tavaszi fagykárok előfordulása és csökkentésének lehetőségei a gyümölcsültetvényekben. ,Agro 21” Füzetek, 45: 64-76.

Szalay L., Papp J. \& Szabó Z. (2000): Evaluation of frost tolerance of peach varieties in artificial freezing tests. Acta Horticulturae. 583: 407-410.

Szalay, L. (2001): Kajszi- és őszibarackfajták fagy- és téltürése. Doktori értekezés. Szent István Egyetem, Budapest (Kézirat)

Timon B. (2000): Ôszibarack. Mezőgazda Kiadó, Budapest

Zayan, M. A. (1981): Különböző kajszibarackfajták hidegtürésének alakulása szénhidrát, fehérje- és az aminosavtartalom függvényében. Kandidátusi Értekezés, MTA, Budapest (Manuscript) 